\title{
Taking Longer, but Finishing Just as Strong: A Comparison of Pell and Non-Pell Study Abroad Participants' GPA and Time-to- Graduation
}

\author{
Steven D. Bell \\ Chris R. Glass \\ Old Dominion University
}

\begin{abstract}
:
Researchers compared Pell-eligible and non-Pell-eligible undergraduate students' pre-study abroad GPA and graduation GPAs and time-to-graduation. The results indicated a longer time-tograduation for Pell-eligible students. However, Pell-eligible students who had studied abroad graduated with comparable GPAs to their non-Pell study abroad peers four and six years postmatriculation. The results suggest that study abroad did not create an undue burden that impeded the success of students from low-income households. We discuss implications for funding priorities, university development offices, and study abroad advising.
\end{abstract}

\section{Introduction}

Fifteen percent of the 1.8 million U.S. students receiving bachelor's degrees studied abroad during their academic program (Institute of International Education [IIE], 2017). Little is known about the relationship between study abroad participation and academic performance and time-tograduation by socioeconomic status, since the Institute for International Education (IIE) and the U.S. Department of Education (USDOE) do not collect data on the socioeconomic status (SES) of study abroad participants (Morse \& Tolis, 2013). The threefold increase in study abroad participation over the last two decades heightens the critical importance of unpacking study abroad participation by students' socioeconomic status (IIE, 2017). Just as "educators realize that international education forms an important part of any curriculum, irrespective of field of study" (IIE, 2010, p. 18), educators recognize the importance of international education as part of the curriculum irrespective of a student's socioeconomic status.

It is essential to understand the extent to which academic performance and time-to-graduation may differ for lower-SES and higher-SES students who study abroad. The purpose of this study was to compare the grade point average (GPA) and time-to-graduation of study abroad participants by Pell-eligible status. We examined five questions:

RQ1: Is there a difference between the expected and the observed time-to-graduation for study abroad participants by Pell-eligible status?

RQ2: Does the increment between pre-study abroad and final semester GPA differ by Pelleligible status? 
RQ3: Does the increment between pre-study abroad and final semester GPA differ due to an interaction between gender and Pell-eligible status?

RQ4: Does the increment between pre-study abroad and final semester GPA differ due to an interaction between race/ethnicity and Pell-eligible status?

RQ5: Does the increment between pre-study abroad and final semester GPA differ due to an interaction between four and six-year graduation status and Pell-eligible status?

\section{Socioeconomic Status and Study Abroad}

Completion of an undergraduate degree is a concrete means to gain entry into the middle class (Baum, Ma, \& Payea, 2013). A "college education has been seen as a means of escape and a pathway of social mobility" (Walpole, 2003, p. 46), which provides substantial individual, social, and economic benefits, and serves as "a critical element in the national quest for equality of opportunity" (Chen \& DesJardins, 2008, p. 179). Good physical health, strong social mobility, and various other quality of life measures are often linked to personal wealth, and the relationship between completion of a college degree and higher personal income is well established within U.S. society (Baum, Ma, \& Payea, 2013).

However, lower-SES and higher-SES students exhibit very different behaviors in high school and in college selection (Paulsen \& St. John, 2002). Lower-SES college students spend less time participating in clubs and groups and work more hours than higher-SES students (Walpole, 2003). More than $90 \%$ of Pell grants are awarded to students in households with annual incomes of less than $\$ 40,000$ (Houle, 2013) and the buying power of the Pell grant has decreased (Chen \& Desjardins, 2008). Lower-SES students also have lower levels of income, attendance, and educational attainment than higher-SES peers (Walpole, 2003).

The growing public interest in the breakdown of college student outcomes by socioeconomic status is illustrated by U.S. News and World Report's inclusion of income-based graduation status data in its rankings since 2012 (Morse \& Tolis, 2013). Researchers have examined the relationship between socioeconomic status and degree completion outcomes. Houle (2013) asserted that “parents' SES is an important determinant of children's academic performance, expectations, and ability to gain access to elite postsecondary institutions" (p. 54). Once in college, SES "has a contextual and positive effect on college completion" (Titus, 2006, p. 393) and "higher family incomes and higher parent education levels are associated with higher degree completion rates" (Baum \& Ma, 2007, p. 37). Nevertheless, SES alone does not account for student college completion rates (Titus, 2006). Instead, Titus (2006) found that "college completion is positively influenced by such demographic-structural characteristics as racial/ethnic diversity" (p. 393). Lundy-Wagner (2012) added that some element of social class is significantly related to college completion for each race/ethnicity, no matter whether the student is White, African American, Asian, or Latino.

Not surprisingly, lower-SES students are more affected by tuition changes than higher-SES students and "financial aid alone is not sufficient to close attainment gaps" (Lundy-Wagner, 2012, p. 13). The amount, regularity, and types of activities students choose to participate in at university can also impact the likelihood of persistence and college completion (Kuh, 2008). Much of what we know about the relationship between socioeconomic status and study abroad has to do with differential participation in study abroad programs (Salisbury, Paulsen, \& Pascarella, 2010, 2011; 
Salisbury, Umbach, Paulsen, \& Pascarella, 2009; Stroud, 2010; Whatley, 2017). Utilizing Perna's (2006) integrated student choice model, Salisbury et al. (2011) investigated factors that influence college freshmen of different racial groups to consider study abroad and found that among all groups, a student's intent to study abroad was related to that student's socioeconomic status. Salisbury et al. (2011) also found that social and cultural capital accumulation prior to and throughout a student's college experience can significantly influence a student's intent to study abroad. In general, college students who received a federal grant were less likely to intend to study abroad than those who did not (Salisbury et al., 2009, 2010, 2011). Yet, evidence suggests that the association between federal grants and intention to study abroad differs for specific student populations. For example, a negative relationship was found between receipt of a federal grant and intent to study abroad among White and female students; yet, a positive relationship was found between receipt and intent to study abroad among Hispanic students (Salisbury et al., 2010, 2011).

Whatley (2017) went beyond research on intent to study abroad (Salisbury et al., 2010, 2011; Salisbury et al., 2009; Stroud, 2010) to examine the financial factors that influenced students to actually study abroad. Similar to research on student intent (Salisbury et al., 2010, 2011; Salisbury et al., 2009; Stroud, 2010), Whatley (2017) found that females were significantly more likely than males to study abroad and that minority students were significantly less likely than White students to study abroad, especially Asian and African American students. In contrast to other research on the relationship between financial factors and intent to study abroad (Salisbury et al., 2009), Whatley (2017) found that need-based and non-need-based grant funding had a positive effect on actual student participation in study abroad. Not surprisingly, like Salisbury et al. (2009), Whatley (2017) found that subsidized and unsubsidized loans, expected family contributions, and financial need negatively impacted study abroad participation.

In summary, several elements related to socioeconomic status affect participation in study abroad. A student's social and cultural connections and financial status, openness to diverse ideas and peoples, and parents' educational attainment all influence participation in study abroad. Additionally, these same elements often pertain to the families of students according to socioeconomic status. And all these elements may have implications for the design, funding, marketing, and promotion of study abroad, especially in terms of the often-repeated goal to increase U.S. student participation in study abroad (IIE, 2017).

\section{Benefits of Study Abroad}

Researchers have highlighted the academic benefits of participation in study abroad programs. Numerous research studies provide evidence that study abroad provides personal (Salisbury, An, \& Pascarella, 2013), academic (Barclay Hamir, 2011; McKeown, 2009), and professional (Preston, 2012; Redden, 2010) benefits for students. Research on the academic benefits of study abroad has investigated foreign language learning (Cubillos \& Ilvento, 2013; Magnan \& Back, 2007), intellectual development (McKeown, 2009), and improved academic performance (Barclay Hamir, 2011; Sutton $\&$ Rubin, 2004, 2010) for participants.

Researchers have also highlighted the benefits of participation in study abroad programs on time-to-degree. Kuh, Kinzie, Schuh, and Whitt (2005) assert that participation in study abroad programs is a high-impact practice that increases student retention and graduation rates. Numerous 
research studies provide evidence for this claim, including evidence that participation in study abroad is related to increased persistence (Young, 2007) and degree completion (O’Rear, Sutton, \& Rubin, 2011; Sutton \& Rubin, 2004, 2010). Barclay Hamir (2011) investigated degree completion and time-to-degree at the University of Texas at Austin (UT Austin); Sutton and Rubin (2010) completed a ten-year longitudinal study on student learning, academic performance, and student graduation rates-what is referred to as the GLOSSARI project-at several campuses of the University of Georgia (UGA) system; Malmgren and Galvin (2008) studied graduation rates of study abroad students at the University of Minnesota Twin Cities (UofM); and Ingraham and Peterson (2004) researched study abroad students' time-to-degree at Michigan State University (MSU).

Although researchers have investigated the academic and time-to-degree benefits of study abroad participation, less is known about the relationship between these potential benefits and students' socioeconomic status. In the end, study abroad is a financial transaction for all participants. Study abroad students commonly are not exempt from normal home university costs of attendance while abroad, and they also incur study abroad program fees (Whatley, 2017). Hence, it is critical to understand the extent to which academic performance and time-to-graduation may differ for lowerSES and higher-SES students who study abroad.

\section{Methodology}

The study posed five research questions tested with demographic variables as independent variables, and GPA and time-to-graduation as dependent variables. A chi-square analysis was used to answer the first research question, and repeated measures analysis of variance (ANOVA) was used to answer the remaining research questions. Repeated-measures analysis of variance was conducted to assess if mean differences existed on GPA by Pell-eligibility status and gender, race/ethnicity, and time-to-graduation, including any two-way interactions between Pell-eligibility status and these factors.

\section{Participants}

We collected data from the institutional records of the complete census of undergraduate students who participated in study abroad programs at Old Dominion University (ODU), a large, urban, high-research-activity public university in the mid-Atlantic region of the United States. We collected data from all undergraduate students who participated in study abroad between the years of 2000 and 2006 to allow analysis of four- and six-year graduation status starting in 2012. Students started at the university as freshmen (50\%), transfer students $(43 \%)$, or continuing students $(7 \%)$ who first enrolled prior to 2000. We removed a small number of records for program participants who were non-degree students, students pursuing second degrees, or who were registered in certificate programs. To protect participants' anonymity, all individual identifiers were stripped from the dataset. Table 1 reports demographic information for the complete census of students who graduated within six years post-matriculation $(\mathrm{N}=609)$. It is noteworthy that the proportion of Pell-eligible students did not vary as a function of type of program. This non-significant distribution likely reflects the unique student population at Old Dominion University, which we describe below. 
Table 1. Demographic characteristics of the sample in the study.

\begin{tabular}{|c|c|c|c|c|}
\hline & $\begin{array}{l}\text { Pell Grant } \\
\mathrm{n}(\%)\end{array}$ & $\begin{array}{l}\text { No Pell } \\
\text { n }(\%)\end{array}$ & $\begin{array}{l}\text { Chi-Square } \\
\text { (df) }\end{array}$ & $p$ \\
\hline & $\mathrm{n}=218$ & $\mathrm{n}=391$ & & \\
\hline Gender & & & $3.077(1)$ & .049 \\
\hline Male & $78(36 \%)$ & $113(29 \%)$ & & \\
\hline Female & $140(64 \%)$ & $278(71 \%)$ & & \\
\hline Race/Ethnicity & & & $33.899(3)$ & .000 \\
\hline Asian/Pacific Islander & $13(6 \%)$ & $19(5 \%)$ & & \\
\hline Black/African American & $51(23 \%)$ & $31(8 \%)$ & & \\
\hline Hispanic & $10(5 \%)$ & $9(2 \%)$ & & \\
\hline White (Non-Hispanic) & $144(66 \%)$ & $332(85 \%)$ & & \\
\hline Type of Program & & & $1.442(2)$ & .485 \\
\hline Affiliate & $66(30 \%)$ & $107(27 \%)$ & & \\
\hline Exchange & $37(17 \%)$ & $81(21 \%)$ & & \\
\hline Faculty-led & $115(53 \%)$ & $203(52 \%)$ & & \\
\hline
\end{tabular}

Old Dominion University has a high percentage of non-traditional, working, and firstgeneration students for which studying abroad is quite outside the norm. In the study period, 26\% of all ODU undergraduates received Pell grants and the average award during this period was $\$ 2,391$ per student per year (Institutional Research and Assessment, 2012). The mean family income of students who received Pell grants during the 2000 to 2006 period was $\$ 21,749$. Seventy-six percent of undergraduates received federal student loan aid. The average amount of federal student loan aid received was $\$ 6,759$ per year. Forty-seven percent of graduating seniors reported that neither of their parents had a bachelor's degree, 29\% reported one parent had a bachelor's degree, and 24\% indicated that both parents had bachelor's degrees.

Seventy percent of ODU seniors in 2011-2012 self-reported that they worked while attending the university (Institutional Research and Assessment, 2012). Of this population, 28\% reported that they worked 30 or more hours weekly, 27\% indicated that they worked 20-29 hours weekly, 20\% responded that they worked 10-19 hours weekly, and 6\% stated that they worked up to ten hours weekly. Within this same population, 17\% reported that they had dependents for who they were responsible; 17\% reported that they were married. The average age of 2011-2012 ODU graduates was 28.6 years. Due to these life circumstances, seventy-five percent of the ODU students who studied abroad from 2006-2007 to 2012-2013 enrolled in short-term programs.

The four- and six-year undergraduate graduation rates for full-time, first-time students who began ODU in fall 2010 were $26 \%$ and 51\%, respectively (NCES, 2018). Among different student populations, the full-time, first-time six-year graduation rate for undergraduates who started ODU in fall 2010 was 63\% (American Indian or Alaska Native), 50\% (Asian), 51\% (Black or African American), 50\% (Hispanic/Latino), 50\% (Native Hawaiian or Pacific Islander), and 51\% (White) (NCES, 2018). Institutional data indicate that ODU's student population was 55\% White or Caucasian, 22\% Black or African American, 6\% Hispanic/Latino, 5\% two or more races, 4\% Asian, 
$5 \%$ not reported, and 3\% international students at the time of the study (Institutional Research and Assessment, 2012).

\section{Measures}

Demographic factors were the independent variables. Students who received a Pell grant during the period of their study abroad program were coded (1=Pell status) and considered lower-SES students for the purposes of the study. Students who did not receive a Pell grant were coded $(0=$ non-Pell status $)$ and considered higher-SES students for the purposes of the study. Researchers also collected data on students' gender and race/ethnicity. Grade point average and time-tograduation were the dependent variables. Grade point average was based on a cumulative four-point GPA scale in the semester immediately preceding study abroad and at the time of graduation. Students were coded based on graduation status (four years or less, five to six years, or more than six years). For all students, including transfer and continuing students, we started the four- and six-year graduation timeline with a student's first semester of higher education enrollment. For example, if a student started at a community college in 2002, transferred to ODU in 2004, and graduated in 2007, then the student graduated in five years. It is not known whether students who took more than six years to graduate did or did not graduate, since the event took place beyond the timeframe of this study.

\section{Results}

The following section provides information on the research questions that were investigated in this study. We conducted chi-square analysis to determine whether there was a significant difference between the observed and expected time-to-graduation for study abroad participants by Pell-eligible status, $X^{2}(2)=9.811, p=.007$ (see Table 2). Pell-eligible students were less likely to graduate in four years or less than non-Pell eligible students, and they were more likely to not have graduated within six years.

Table 2. Analysis of time-to-graduation by Pell grant status.

\begin{tabular}{lll}
\hline Time-to-Graduation & $\begin{array}{l}\text { Pell Grant } \\
n(\%)\end{array}$ & $\begin{array}{l}\text { No Pell } \\
n(\%)\end{array}$ \\
\hline 4 years or less & $176(53 \%)$ & $316(62 \%)$ \\
5 to 6 years & $88(27 \%)$ & $131(26 \%)$ \\
More than 6 years & $66(20 \%)$ & $64(12 \%)$ \\
\hline
\end{tabular}

A repeated measures ANOVA determined that there was no significant main effect of Pelleligible status on changes in mean GPA between pre-study abroad and final semester, $F(1,597)=$ $0.037, p=.847$ (see Table 3).

Table 3. Mean pre-study abroad and graduation GPA by Pell grant status.

\begin{tabular}{lll}
\hline & Pell Grant & No Pell \\
Time & M(SD) & M(SD) \\
& $n=218$ & $n=391$ \\
\hline Pre-Study Abroad GPA & $3.25(.49)$ & $3.26(.47)$ \\
Graduation GPA & $3.26(.45)$ & $3.28(.44)$ \\
\hline
\end{tabular}


There was a significant main effect of gender on changes in mean GPA between pre-study abroad and the final semester, $F(1,597)=6.036, p=.014$ (see Table 4), but the interaction of gender and Pell-eligibility was not significant, $F(1,597)=0.212$, $p=.646$. Contrasts revealed that GPAs for female study abroad participants were significantly higher than GPAs for male study abroad participants, $F(1,597)=6.036, r=.089$.

Table 4. Mean pre-study abroad and graduation GPA by gender and Pell grant status.

\begin{tabular}{lllll} 
& Female & & Male \\
\hline \multirow{2}{*}{ Time } & Pell Grant & No Pell & Pell Grant & No Pell \\
& M(SD) & M(SD) & M(SD) & M(SD) \\
& $n=140$ & $n=278$ & $n=78$ & $n=113$ \\
\hline Pre-Study Abroad GPA & $3.29(.44)$ & $3.30(.46)$ & $3.17(.56)$ & $3.15(.49)$ \\
Graduation GPA & $3.32(.41)$ & $3.33(.42)$ & $3.15(.54)$ & $3.14(.47)$ \\
\hline
\end{tabular}

There was no significant main effect of race/ethnicity on changes in mean GPA between prestudy abroad and the final semester, $F(3,597)=0.193, p=.901$ (see Table 5), and the interaction of race/ethnicity and Pell-eligibility was not significant, $F(3,597)=0.630, p=.596$.

Table 5. Mean pre-study abroad and final semester GPA by race/ethnicity and Pell grant status.

\begin{tabular}{|c|c|c|c|c|c|c|c|c|}
\hline & $\begin{array}{l}\text { Asian/Pacif } \\
\text { Islander }\end{array}$ & ific & $\begin{array}{l}\text { Black/Afric } \\
\text { American }\end{array}$ & ican & Hispanic & & $\begin{array}{l}\text { White } \\
\text { (Non-Hispan }\end{array}$ & anic) \\
\hline \multirow{3}{*}{ Time } & Pell Grant & No Pell & Pell Grant & No & Pell Grant & No & Pell Grant N & No Pell \\
\hline & $\mathrm{M}(\mathrm{SD})$ & $\mathrm{M}(\mathrm{SD})$ & $\mathrm{M}(\mathrm{SD})$ & $\mathrm{M}(\mathrm{SD})$ & $\mathrm{M}(\mathrm{SD})$ & $\mathrm{M}(\mathrm{SD})$ & $\mathrm{M}(\mathrm{SD})$ & $\mathrm{M}(\mathrm{SD})$ \\
\hline & $\mathrm{n}=13$ & $\mathrm{n}=19$ & $\mathrm{n}=51$ & $\mathrm{n}=31$ & $\mathrm{n}=10$ & $\mathrm{n}=9$ & $\mathrm{n}=144$ & $\mathrm{n}=332$ \\
\hline \multicolumn{2}{|c|}{ Pre-Study Abroad GPA3.18 (.45) } & $3.24(.52)$ & $3.07(.47)$ & $3.12(.41)$ & $2.93(.65)$ & $3.33(.45)$ & $3.29(.47) 3$ & $3.27(.47)$ \\
\hline Graduation GPA & $3.17(.47)$ & $3.26(.50)$ & $3.07(.45)$ & $3.16(.40)$ & $2.94(.58)$ & $3.29(.43)$ & $3.34(.43) 3$ & $3.29(.44)$ \\
\hline
\end{tabular}

There was a significant main effect of time-to-graduation on changes in mean GPA between pre-study abroad and the final semester, $F(1,597)=6.329, p=.012$ (see Table 6 ), but the interaction of time-to-graduation and Pell-eligibility was not significant, $F(1,597)=0.191, p=.663$. Contrasts revealed that study abroad participants who graduated in four years or less had significantly higher GPAs than study abroad participants who graduated in five to six years, $F(1,597)=6.329, r=.093$.

Table 6. Mean pre-study abroad and final semester GPA by time-to-graduation and Pell grant status.

\begin{tabular}{|c|c|c|c|c|}
\hline \multicolumn{5}{|c|}{ Time-to-Graduation } \\
\hline & Pell Grant & No Pell & Pell Grant & No Pell \\
\hline & $\mathrm{M}(\mathrm{SD})$ & $\mathrm{M}(\mathrm{SD})$ & $\mathrm{M}(\mathrm{SD})$ & $\mathrm{M}(\mathrm{SD})$ \\
\hline Time & $n=188$ & $n=379$ & $n=40$ & $n=29$ \\
\hline \multicolumn{2}{|c|}{ Pre-Study Abroad GPA3.28 (.49) } & $3.33(.46)$ & $3.18(.47)$ & $3.08(.46)$ \\
\hline Graduation GPA & $3.30(.46)$ & $3.35(.40)$ & $3.15(.47)$ & $3.07(.47)$ \\
\hline
\end{tabular}




\section{Discussion}

The purpose of this study was to compare the grade point average and time-to-graduation of study abroad participants by Pell-eligible status. As expected, the results indicated a significant difference in the time-to-graduation for study abroad participants by Pell-eligible status, with a longer time-to-degree for Pell-eligible students. Nonetheless, Pell-eligible graduates who had studied abroad graduated with comparable GPAs to their higher-SES, non-Pell study abroad peers at fourand six-years post-matriculation. These results suggest that study abroad did not create an undue burden that impeded the success of these lower-SES students any more than their higher-SES peers who had also studied abroad.

The research literature is replete with evidence that students from middle- and high-income households comprise the majority of study abroad program enrollments (Salisbury et al., 2009; Salisbury et al., 2010, 2011; Stroud, 2010; Whatley, 2017). Student socioeconomic status data is not collected or maintained by national organizations (e.g., IIE, USDOE, etc.) and many universities do not breakout student outcomes by household income. This hampers insight into the potential benefits of study abroad programs for low-income students in particular. A small body of evidence suggests there is a relationship between study abroad participation and persistence for low-income students (Young, 2007). The results of this study provide further evidence that study abroad does not place an undue burden on lower-SES students' academic success and, therefore, there is no reason to limit studying abroad to middle- and higher-income students based on this rationale.

The GLOSSARI project found significant relationships between study abroad and graduation at four and five years (O’Rear, Sutton, \& Rubin, 2011; Rubin \& Sutton, 2001; Sutton \& Rubin, 2004, 2010). The results obtained indicate that graduation rates for students who studied abroad, regardless of their Pell-eligible status, were well above the average for the ODU student population in general. The time-to-graduation for Pell-eligible study abroad participants, 53\% and 80\%, and non-Pell-eligible study abroad participants, $62 \%$ and $88 \%$, far exceed ODU's four- and six-year overall graduation rates, $21 \%$ and $51 \%$, for the same time period (Institutional Research and Assessment, 2012). These results suggest that, overall, study abroad did not put an undue burden on low-income ODU students' ability to complete college, and it further underscores the need for continued research into the role of study abroad GPA and college completion that builds on the GLOSSARI project.

Finally, low-income students who studied abroad took longer to graduate than their higher-SES peers but finished with GPAs comparable to higher-SES peers who also had studied abroad. It is not surprising that Pell-eligible students took longer to graduate than their higher-SES peers. Xu et al. (2013) found that study abroad had a significant effect on graduation at five and six years postmatriculation, but not at four years post-matriculation. The current study adds to research on completion with results that suggest that there is little evidence that study abroad is detrimental to lower-SES students' grade point average.

\section{Implications for Practice}

The results of this study have implications for funding priorities, university development offices, and study abroad advising. First, the results of this study have implications for funding priorities. It is important to make an evidence-based case that study abroad is not detrimental to the 
academic success of lower-SES students. Lower-SES students often work part- or full-time while taking college courses (Baum \& Ma, 2007; Lundy-Wagner, 2012). These work demands often limit the participation of Pell grant students in study abroad programs (Whatley, 2017). Therefore, identifying and allocating targeted funding to increase the number and percentage of Pell grant recipients who study abroad may be constructive. Administrators may be able to bolster the case for additional resources if they collect and analyze institutional data on socioeconomic status as it relates to academic outcomes and college completion.

Second, the results have implications for university development officers as they reach out to potential donors to support study abroad initiatives. About one-fifth of U.S. higher education institutions have developed a strategy to raise money for campus internationalization efforts (ACE, 2017). Donors may be motivated to give if they understand the tangible impact of their gifts on student success. University development officers can point to comparable GPAs of participants in this study — as well as overall degree completion rates — as evidence of the potential impact of their gift. Development officers may be able to use this type of data to inform potential donors of the potential return-on-investment of their financial contributions when they fund scholarships that make study abroad more accessible for lower-SES students.

Finally, the results suggest that study abroad advisors should not advise lower-SES students against participating in studying abroad simply out of concerns that it might impede their academic success. Advisors should recognize that while lower-SES students face greater financial pressures, study abroad does not necessarily put their academic success at risk. In fact, study abroad is a means for all students to challenge, diversify, and deepen their learning and experiences (Kuh et al., 2005), and it provides personal, academic, and professional benefits (Chen \& DesJardins, 2008; Walpole, 2003). Study abroad professionals may transparently inform lower-SES students about these benefits and how a carefully chosen study abroad program is unlikely to impede their academic success.

\section{Limitations and Further Research}

This study has several limitations. First, the sample did not include a comparison group of ODU students who did not study abroad; therefore, no causal claims may be made about the impact of study abroad on Pell-eligible students' GPA or time-to-graduation. Future research could collect similar institutional data from participants that include a non-study abroad comparison group. Second, this study took place at one institution, Old Dominion University, which has a high percentage of non-traditional, working, and first-generation students for which studying abroad is quite outside the norm. ODU is an urban, nonresidential school with many nontraditional students. Therefore, the demographic makeup of students in the current study may not reflect the makeup of students at other types of institutions or the overall U.S. college student population. Researchers could expand on this study by collecting data from multiple institutions that better approximate the overall U.S. undergraduate student population to draw stronger conclusions than can be made from the data in this study. Finally, no data is available for participants who took more than six years to graduate. No GPA comparisons or time-to-graduation comparisons could be made since none of these study abroad participants had completed college in the timeframe of this study. 


\section{Conclusion}

This study contributes to a small but growing body of research on study abroad for students from low-income households. Our analysis indicates that Pell-eligible students who participated in study abroad took longer to graduate than study abroad participants from higher-income households. Nonetheless, no comparable difference existed in mean GPAs between Pell-eligible and non-Pell eligible students. We believe further research on the relationship between socioeconomic status and study abroad intent, participation, and outcomes is essential in order to advance educational equity for low-income students.

\section{References}

Barclay Hamir, H. (2011). Go abroad and graduate on-time: Study abroad participation, degree completion, and time-to-degree. (Unpublished doctoral dissertation). University of NebraskaLincoln, Lincoln, NE.

Baum, S., \& Ma, J. (2007). Education pays: The benefits of higher education for individuals and society. Retrieved from https://advocacy.collegeboard.org/.../2009_Trends_Educat

Baum, S., Ma, J., \& Payea, K. (2013). Education pays 2013: The benefits of higher education for individuals and society. Retrieved from http://trends.collegeboard.org/sites/default/files/ educationpays-2013-full-report.pdf

Chen, R., \& DesJardins, S. L. (2008). Exploring the effects of financial aid on the gap in student dropout risks by income level. Research in Higher Education, 49(1), 1-18. doi: 10:1007/s11162-007-9060-9

Chen, R., \& DesJardins, S. L. (2010). Investigating the impact of financial aid on student dropout risks: Racial and ethnic differences. The Journal of Higher Education, 81(2), 179-208, doi:10.1353/jhe. 0.0085

Cubillos, J. H., \& Ilvento, T. (2013). The impact of study abroad on students' self-efficacy perceptions. Foreign Language Annals, 45(4), 494-511.

Houle, J. N. (2013). Disparities in debt: Parents' socioeconomic resources and young adult student loan debt. Sociology of Education, 87(1), 53-69. doi: 10.1177/0038040713512213

Ingraham, E. C., \& Peterson, D. L. (2004). Assessing the impact of study abroad on student learning at Michigan State University. Frontiers: The Interdisciplinary Journal of Study Abroad, 10(1), 83-100.

Institute of International Education. (2010). Open Doors report on international educational exchange. New York: Institute on International Education.

Institute of International Education (IIE). (2017). Open Doors report on international educational exchange. New York: Institute on International Education.

Office of Institutional Research and Assessment, Old Dominion University. (2012, December). Senior student satisfaction survey 2011-12.

Kuh, G. D. (2008). High-impact educational practices: What they are, who has access to them, and why they matter. Washington, DC: Association of American Colleges and Universities.

Kuh, G. D., Kinzie, J., Schuh, J. H., \& Whitt, E. J. (2005). Student success in college: Creating conditions that matter. San Francisco, CA: Jossey-Bass.

Lundy-Wagner, V. (2012). Classifying ethnicity/race and gender: An intersectional critique of bachelor's degree completion research. InterActions: UCLA Journal of Education and Information Studies, $8(2), 1-21$.

Magnan, S. S., \& Back, M. (2007). Social interaction and linguistic gain during study abroad. Foreign Language Annals, 40(1), 43-61. doi: 10.1111/j.1944-9720.2007.tb02853.x

Malmgren, J., \& Galvin, J. (2008). Effects of study abroad participation on student graduation rates: A study of three incoming freshman cohorts at the University of Minnesota, Twin Cities. NACADA Journal, 28, 29-42.

McKeown, J. S. (2009). The first-time effect: The impact of study abroad on college student intellectual development. Albany, NY: State University of New York Press. 
Morse, R., \& Tolis, D. (2013, October 17). Measuring colleges' success graduating low-income students [Blog post]. Retrieved from http://www.usnews.com/education/blogs/college-rankingsblog/2013/10/17/measuring-colleges-success-graduating-low-income-students

National Center for Education Statistics [NCES] (2018), Institute of Education Sciences, U.S. Department of Education, College Navigator. Retrieved from https://nces.ed.gov/collegenavigator/?q=old+dominion+university\&s=all\&id=232982

O'Rear, I., Sutton, R. C., \& Rubin, D. L. (2011). The effect of study abroad on college completion in a public university system. Retrieved from http://www.glossari.uga.edu

Paulsen, M. B. \& St. John, E. P. (2002). Social class and college costs: Examining the financial nexus between college choice and persistence. Journal of Higher Education, 73(2), 189-236.

Perna, L. (2006). Studying college access and choice: A proposed conceptual model. In J. C. Smart (Ed.), Higher education: Handbook of theory and research (pp. 99-157). Dordrecht, Netherlands: Springer. doi: 10.1007/1-4020-4512-3

Preston, K. (2012). Recent graduates survey: The impact of studying abroad on recent college graduates' careers, 2006-2011. IES Abroad. Retrieved from http://www.iesabroad.org/study-abroad/why/careerbenefits

Redden, E. (2010, July 13). Academic outcomes of study abroad. Inside Higher Ed. Retrieved from http://www.insidehighered.com/news/2010/07/13/abroad

Rubin, D. L., \& Sutton, R. C. (2001). Assessing student learning outcomes from study abroad. International Educator, 10(2), 30-31.

Salisbury, M. H., An, B. P., \& Pascarella, E. T. (2013). The effect of study abroad on intercultural competence among undergraduate college students. Journal of Student Affairs Research and Practice, 50(1), 1-20. doi: 10.1515/jsarp-2013-0001

Salisbury, M. H., Paulsen, M. B., \& Pascarella, E. T. (2010). To see the world or stay at home: Applying an integrated student choice model to explore the gender gap in the intent to study abroad. Research in Higher Education, 51(7), 615-640. doi: 10.1007/s11162-010-9171-6

Salisbury, M. H., Paulsen, M. B., \& Pascarella, E. T. (2011). Why do all the study abroad students look alike? Applying an integrated student choice model to explore differences in the factors that influence white and minority students' intent to study abroad. Research in Higher Education, 52(2), 123-150. doi: 10.1007/s11162-010-9191-2

Salisbury, M. H., Umbach, P. D., Paulsen, M. B., \& Pascarella, E. T. (2009). Going global: Understanding the choice process of the intent to study abroad. Research in Higher Education, 50(2), 119-43. doi: 10.1007/s11162-008-9111

Stroud, A. H. (2010). Who plans (not) to study abroad? An examination of U.S. student intent. Journal of Studies in International Education, 14(5), 491-507. doi: 10.1177 .1028315309357942

Sutton, R. C., \& Rubin, D. L. (2004). The GLOSSARI project: Initial findings from a system-wide research initiative on study abroad learning outcomes. Frontiers: The Interdisciplinary Journal of Study Abroad, 10(2), 65-82.

Sutton, R. C., \& Rubin, D. L. (2010, Jun.). Documenting the academic impact of study abroad: Final report of the GLOSSARI project. Presentation at the NAFSA Annual Conference, Kansas City, MO.

Terenzini, P. T., Cabrera, A. F., \& Bernal, E. M. (2001). Swimming against the tide: The poor in American higher education. College Board Research Report No. 2001-1. College Entrance Examination Board, New York, NY.

Titus, M. A. (2006). Understanding college degree completion of students with low socioeconomic status: The influence of the institutional financial context. Research in Higher Education, 47(4): 371-398. doi: 10.1007/s11162-005-9000-5

Walpole, M. (2003). Socioeconomic status and college: How SES affects college experiences and outcomes. Review of Higher Education, 27(1), 45-73.

Whatley, M. (2017). Financing study abroad: An exploration of the influence of financial factors on student study abroad patterns. Journal of Studies in International Education, 21(5), 431-449. 
Xu, M., de Silva, C. R., Neufeldt, E., \& Dané, J. H. (2013). The impact of study abroad on academic success: An analysis for first-time students entering Old Dominion University, Virginia, 2000-2004. Frontiers: The Interdisciplinary Journal of Study Abroad, 23(2), 90-103.

Young, D. Y. (2007). Persistence at a liberal arts university and participation in a study abroad program. Frontiers: The Interdisciplinary Journal of Study Abroad, 15(2), 93-110. 